\title{
Theorizing interactions of migrant transnationalism and integration through a multiscalar approach
}

\author{
Marta Bivand Erdal(D
}

\author{
Correspondence: marta@prio.org \\ Peace Research Institute Oslo, PO \\ Box 9229, Grønland, NO-0134 Oslo, \\ Norway
}

\begin{abstract}
The aim of this article is to theorize interactions between migrant transnationalism and integration using a multiscalar approach. For migrant transnationalism scholars, attention to simultaneity in transnational social fields is given. However, much migration research in Europe continues to suffer from an 'integration bias', which under-appreciates the salience of simultaneity within transnational social fields in many migrants' lives, and implicitly assumes a zero-sum approach to societal membership. Drawing on interviews with migrants in Oslo (Norway) a multiscalar analytical approach is adopted. The salience of where things happen and how they are understood, depending on the perspective of involved actors, across time, space and position, emerges when using this multiscalar approach. Identifying the roles of nested, taxonomical, but also emergent and perspective scales allows a fresh theoretical engagement with interactions between migrant transnationalism and integration, showing how simultaneity and (productive) friction result from additive, synergistic and even apparently antagonistic interactions.
\end{abstract}

Keywords: Migrant experience, Transnationalism, Integration, Friction, Simultaneity

\section{Introduction}

The empirical realities of transnational social fields, where individuals maintain some degree of societal membership and belonging across societies, are by now well established (Glick Schiller et al. 1992; Levitt and Glick Schiller 2004; Hamaz and Vasta 2009). But, in both scholarship within the field of migration studies and in policy circles, a lingering uncertainty remains: can a person really belong 'here', if they also belong 'there'? This ambiguity is reflected in the fact that while many European countries have accepted dual citizenship, they have also tightened the requirements for naturalization for new citizens (Bloemraad 2015; Vink et al. 2019). This article provides an effort to theorize the relationship between migrant transnationalism and integration, through a multiscalar approach, adding to the growing body of work focusing on this relationship empirically (Bilgili 2014; Dekker and Siegel 2013; Carling and Pettersen 2014; Erdal and Oeppen 2013; Gropas et al. 2014; Schans 2009; Schunck 2011; Snel et al. 2006).

(c) The Author(s). 2020 Open Access This article is licensed under a Creative Commons Attribution 4.0 International License, which permits use, sharing, adaptation, distribution and reproduction in any medium or format, as long as you give appropriate credit to the original author(s) and the source, provide a link to the Creative Commons licence, and indicate if changes were made. The images or other third party material in this article are included in the article's Creative Commons licence, unless indicated otherwise in a credit line to the material. If material is not included in the article's Creative Commons licence and your intended use is not permitted by statutory regulation or exceeds the permitted use, you will need to obtain permission directly from the copyright holder. To view a copy of this licence, visit http://creativecommons.org/licenses/by/4.0/. 
The question of potentially simultaneous membership in societies 'here' and 'there' across transnational social fields, is one which is hotly debated (see e.g. Waldinger 2017): To what extent do migrants retain any tangible degree of membership in societies of origin, over time? And to what extent do they gain any tangible degree of membership in societies of settlement, over time? Are these questions or formal membership via citizenship, or rather informal questions - of felt belonging or of experienced recognition? Or are both formal and informal ties needed? I propose to consider questions of membership in a processual manner, acknowledging the simultaneity for many migrants of membership - of some sort - in their two societies of attachment (Brubaker 2010; Mazzucato 2008; Erdal and Sagmo 2017).

In research on migrant transnationalism the simultaneity of life 'here' and 'there' is often pointed to as contributing to the emergence of transnational social fields as meaningful spatial units in people's lives, and hence in analyses thereof (Levitt and Glick Schiller 2004; Mazzucato 2008; Smith 2005). However, the implication of this simultaneity in migrants' lives, for their membership in one or both societies of attachment, often becomes a backdrop to other discussions, rather than developed as a foci of its own in migration research (but see Bilgili 2014, Mazzucato 2008, Tsuda 2012).

A multiscalar approach to the relationship between migrant transnationalism and integration can contribute to moving beyond an acknowledgment of simultaneity (Levitt and Glick Schiller 2004), to a deeper understanding of the dynamics of simultaneity as constitutive of transnational social fields (see also Mazzucato 2009). The observation that simultaneity is a core trait of experiences of migrant transnationalism has of course been made since the early 1990s (Glick Schiller et al. 1992). Yet, few efforts have been made to theorize the interplay of migrant transnationalism and integration, foregrounding both simultaneity and the inherent friction which lies in always not being somewhere else (Dominges 2015; Ley 2013; Nagel and Staeheli 2008; Smith 2005).

A multiscalar approach builds first, on the conceptual and methodological insights that scales need not be hierarchical and nested (Xiang 2013), but rather that scales may be relationally produced and dynamic (Moore 2008). And second, that scales may also be, emergent and perspectival, foregrounding change over time and agency (Çağlar and Glick Schiller 2015; Xiang 2013). A multiscalar approach offers tools to foreground the salience at once of where things happen but also, how they are understood, which depends on the perspective of involved actors, across time, space and position. A multiscalar approach thus allows a more thorough engagement with the interactions of migrant transnationalism and integration as unfolding processes.

Migrant transnationalism and integration ${ }^{1}$ are both understood in this article from an actor-oriented perspective, which is neither to dismiss critical approaches to the term integration (Rytter 2019), the salience of policies, nor the many real challenges associated with the politics of belonging (Antonsich 2010; Yuval-Davis 2010). However, a bottom-up focus on membership in two societies simultaneously - which research on the interplay of migrant transnationalism and migrant integration is ultimately about - allows to take seriously the people and practices that constitute societies (Eriksen 2011).

${ }^{1}$ I use the term integration, rather than e.g. assimilation, here, as this is the term commonly used in Europe. 
The empirical basis for this article is 22 semi-structured interviews inspired by life history methodology collected in Oslo, Norway, as part of a research project about active citizenship in culturally and religiously diverse societies (Horst et al. 2020). I now proceed to introduce the multiscalar approach adopted to theorize interactions of transnationalism and integration.

\section{Multiscalarity and the interaction of transnationalism and integration}

Migration brings to the fore the multiscalarity of human experience (Çağlar and Glick Schiller 2015), as distance and borders bring attention to different types of scales. Recent contributions to discussions of multiscalarity in migration studies have focused on understanding the locality and the city (Çağlar and Glick Schiller 2015). Questions of multiscalarity are also central to the field of migrant transnationalism. Yet the dynamics of simultaneity, as these impact relationships between migrant transnationalism and integration, have arguably not been scrutinized sufficiently.

The transnational perspective questions assumptions about the salience of any one given scale for the purposes of understanding migrants' experiences and choices (Wimmer and Glick Schiller 2003). This has led to including a focus on migrants' engagements 'back home', as a redress to the dominating attention given to integration processes for a long time in migration research (Lacroix 2016; Mügge 2016). Focusing on transnational ties, is an acknowledgement of individuals' life worlds that traverse international borders, connecting the places which matter in migrants' own experience.

Yet, such transnational social fields, whilst inherently spatial, are often inadequately interrogated from a spatial perspective (Collyer and King 2015), and perhaps particularly so when it to comes to the role of scales. Therefore, a multiscalar approach provides opportunities for furthering theorization. Scales are often seen as levels in a hierarchy, as a taxonomical nested scale, moving from neighborhood, to city, to nationstate, to global (Xiang 2013; Çağlar and Glick Schiller 2015).

Alternatively, scale is usefully approached through human experience - as emergent. Here, 'what matters is not what a scale looks like, but how it is made into reality, what it does for the actors and the consequences it leads to' (Xiang 2013, p. 285): Thus taking the example of migrants' engaged in transnational practices, a hierarchy of nested scales will not be experienced identically by all. Some might acknowledge two parallel taxonomical scales of national - regional - local scales which are nested, e.g. one in Norway and one in Eritrea. Yet, emergent scales are often not compartmentalized, but rather experienced as part of a single whole, perhaps joined by a notion of a global humanity, at an overarching scale. Other times, a division is necessitated by, for instance, the enforcement of borders, whereby travel between places is hindered, and life worlds are experienced as split, although connected.

So, a multiscalar approach to the interactions of migrant transnationalism and integration, builds on an acknowledgment of the variety of nested scales, as well as on emergent scales. But scale is also a perspectival device, for how we analytically understand and seek to give meaning to practices and processes in the world (Xiang 2013). In the geographical literature, the multiplicity of scale in the sense of both ontological and epistemological realities, where questions of positionality, embeddedness and change are central, has been argued for some time (Moore 2008). For, if scale and how 
we seek to understand its effects analytically is not seen as plural and as political, things in the world, become conflated with perspectives on the world (Brubaker and Cooper 2000, p. 5). Arguably, it is therefore useful to think of scales as taxonomical and nested, for that is how (geographic) scales tend to be represented and therefore become social reality, but to simultaneously complement such an understanding with that of emergent scales from migrants' experiences, and to ensure a plurality of perspectival scales, giving voice to potential friction about the epistemology of scales.

\section{Approaching migrant transnationalism and integration as processes}

The volume of studies of migrant transnationalism published since the 1990s is testament both to the salience of the empirical phenomenon of migrants' cross-border engagements, and to the need for epistemological approaches to the study of international migration with an ontology that can transcend the contemporary nation-state system. Meanwhile, studies of migrant transnationalism contrast in their epistemological approach and the term 'transnational' is used in radically different ways (Carling 2007).

Approaching transnationalism through the lens of 'being' and 'doing' (Levitt and Glick Schiller 2004), acknowledges the salience of empirically measurable cross-border activities - 'doing', but at the same time also encompasses the not always easily measurable aspects of life worlds which span transnational social fields - 'being'. These are life worlds which in people's own terms are meaningfully anchored spatially in a 'here' and 'there' (and possibly an elsewhere).

Thomas Lacroix (2016) conceptualizes a 'transnational paradigm', cognizant of the interplay of structure and agency, in the ways in which migrants' transnationalism actually takes form and is articulated. Such a transnational paradigm moves beyond the early efforts to counter the dominance of the integration focus in migration studies (Lacroix 2016), and also beyond the still important critique of methodological nationalism in the social sciences (Wimmer and Glick Schiller 2003), and rather builds on an understanding grounded in the existence of 'a lived transnational temporality' (Lacroix 2016, p. 188).

A transnational paradigm focusing on 'a lived transnational temporality' allows for the multiscalarity of lived experience to appear, foregrounding emergent scales, but also attentive to the relevance of taxonomical scales, especially in the ways in which these influence actors' perspectival scales (Xiang 2013). Thus, the structural potential of scale, in the sense of nested scales, where the nation-state has an ordering power over the local, are recognized, yet not reified, but acknowledged as an epistemological reality. This epistemological reality shapes the ways in which we are able to generate meaning and understanding of social phenomena, without necessarily concluding that an understanding foregrounding the nation-state scale is more - or less - salient in ontological terms.

Meanwhile, the negotiation of membership and belonging inevitably involves the individual as well as the society, as a collective of individuals in some political relationship with one another and the state; a society which is constituted by people and practices of membership and belonging (Eriksen 2011).

Multiscalarity in relation to migrant transnationalism and integration, focuses on emplacement (Çağlar and Glick Schiller 2015), acknowledging the relevance of individual's membership in societies both 'here' and 'there'. A multiscalar approach to social 
processes - such as those of migrant transnationalism and integration - necessitates inclusion of both practices and consciousness (Moore 2008), which may not fit neatly into pre-given taxonomical and nested scales. A radical approach to multiscalarity entails the need to foreground emergent scales, as these are experienced and discussed by people themselves, while allowing for a multiplicity of potentially relevant perspectival scales (Xiang 2013; Çağlar and Glick Schiller 2015).

Common definitions see integration as a two-way process of adaptation, where newcomers find their places, whilst society facilitates these processes by ensuring there is room to find space, and by implication, both newcomers and society undergo change (Kivisto 2003). While contested if referred to in terms of a pure multiculturalist ideology of minority group rights, an understanding of integration processes as above is largely accepted, although the extent to which society should undergo change as a result of immigration is a heated topic. Hence, here, integration can be understood as what Peter Kivisto refers to as the inevitable process of adaptation which migrants - at all times - have undertaken, with some implications for their surroundings, and with some dependence on their surrounding's approach to their presence (Kivisto 2003).

\section{Interactions of migrant transnationalism and integration}

While research on migrants' transnational ties and their simultaneous integration in settlement societies has abundantly demonstrated the reality of multiple ties to two or more societies, a lingering assumption often remains, that true societal membership, can only be singular (Hamaz and Vasta 2009). Whether or not belonging is a zero-sum game (Antonsich 2010), has been an underlying question driving debates over the interactions of migrant transnationalism and integration, and whether one hinders the other, or not (Dekker and Siegel 2013; Gropas et al. 2014). In the European context there is some convergence around the idea that migrant transnationalism and integration are not a zero-sum game, but rather simultaneous and parallel processes with differing outcomes at individual and group levels (Bilgili 2014; Dekker and Siegel 2013; Carling and Pettersen 2014; Gropas et al. 2014; Schans 2009; Schunck 2011).

In the US context, the debates about the interplay of assimilation (the more common term in the US) and transnationalism have been far more heated (Landolt et al. 1999; Itzigsohn and Giorguli-Saucedo 2002; Guarnizo et al. 2003; Levitt 2001; Portes et al. 2002). There is some disagreement about the interpretation and generalizability of conclusions from particular studies, about the extent to which it is likely that transnational ties will last beyond the migrant generation, and the degree to which the average migrant can be said to engage in 'transnationalism' (Waldinger and Fitzgerald 2004; Waldinger 2008). Similar reflections on the limits to 'transnationalism' have also emerged in Europe (see e.g. Al-Ali et al. 2001).

Waldinger (2017) points to the unresolved relationship between assimilation and transnationalism and argues that claims to their compatibility do not sufficiently acknowledge the friction which international migration causes. This is a two-sided, cross-border friction, first, of dissimilation of migrants in origin contexts, where belonging becomes questioned as migrants become more shaped by their settlement contexts. Second, there is friction in settlement contexts, as there are parallel trends of xenophobia and xenophilia 
at work, where sections of the native population reject the international interconnectedness and diversification of their own societies which international migration entails (ibid.).

It remains unclear, however, to what extent it can be assumed that friction at individual and societal levels necessarily outweighs benefits which international interconnectedness involves, and why the trend of xenophobia is assumed to have to conquer that of xenophilia, at individual and societal levels, and in both cross-border contexts. Given the political climate in Europe and the US in recent years, a rather dystopian view of prospects for the compatibility of migrant transnationalism and integration, reflecting a world interconnected (among other) by international migration, is understandable. Yet, it should be acknowledged that this is one view, and it is one that implicitly concurs that in practice, belonging either is - or at least is seen by most people to be - a zerosum game. Whilst the latter is probably true, migration studies have abundantly shown empirically that the former is not.

Whilst it is hard to disagree with Waldinger (2017) that cross-border connections showcase the salience of borders, both in territorial and social terms, I argue that a multiscalar perspective may contribute alternative interpretations of the relationship between migrant transnationalism and integration. One where the salience of emergent scales, as well as perspectival scales, is acknowledged equally centrally as those of taxonomical scales, especially of the nation-state order of things (Malkki 1995), which tends to dominate.

An emergent literature on the interactions of migrant transnationalism and integration seeks to typologise interactions, beyond the question of compatibility or not (Dekker and Siegel 2013). Such typologies draw on more quantitatively oriented generalizations, whereby patterns of interactions may be grouped as; i) strong integration + strong transnationalism; ii) strong integration + weak transnationalism; iii) weak integration + strong transnationalism; iv) weak integration + weak transnationalism, without causal claims about the directionality of mutual effects (Carling and Pettersen 2014). Analytical generalizations, also building on qualitative analyses, suggest the possibilities of antagonistic/ negatively reinforcing or synergistic/positively reinforcing relationships, or additive/side by side relationships, or zero-sum relationships (Erdal and Oeppen 2013; Dekker and Siegel 2013; Gropas et al. 2014; Tsuda 2012).

A review of studies focusing on the interactions of migrant transnationalism and integration indicates firstly, that there are in fact not that many studies which focus on addressing these relationships (exceptions above), secondly, that the quantitativequalitative divide persists, thirdly, that many studies focus on particular spheres. E.g. studies show the impact of stronger or weaker integration and transnational ties for return intentions (Carling and Pettersen 2014), for economic ties (Carling et al. 2012; Kuuire et al. 2016; Erdal 2012) in relation to political participation 'here' and 'there' (Chaudhary and Moss 2019; Cristina et al. 2014), or in relation to co-development programs (Lacroix 2016; Ostergaard-Nielsen 2011). But despite significant advances in knowledge about interaction of migrant transnationalism and integration, arguably, a dynamic multiscalar approach is yet to be applied in this field of study.

The following section details the methods and data this article draws on. The subsequent section presents the data analysis which focuses on the multiscalarity of migrant experience, drawing on four selected migrant stories. Because, by 'focus[ing] more on people's actual experiences, perceptions, and strategies, what is at stake is not the 
expansion and contraction of physical scope of mobility, nor the jumping up or down between pre-given levels, or the actors' defiance of established boundaries. What matters is the creation of new scales. The emergent scale can be undefinable and unmappable in the given scalar schema' (Xiang 2013, p. 297). But by exploring what types of multiscalarity appears in migrants experiences, it is possible to tease out the ways in which transnationalism and integration interact, theoretically and empirically. A multiscalar approach to migrants' stories, allows seeing different spheres, temporalities and geographies. The discussion following these four stories examines the extent to which these interactions might be typologized as additive, synergistic or antagonistic (Erdal and Oeppen 2013), and highlights the ways in which simultaneity and the space for friction are not sufficiently encompassed in existing theorization of the interactions of migrant transnationalism and integration.

\section{Methods and data}

This article draws on 22 semi-structured interviews, conducted in Oslo, Norway in 2015, within a larger research project Active Citizenship in Culturally and Religiously Diverse Societies. ${ }^{2}$ The focus of the research was on active citizenship, broadly conceived, in the context of culturally and religiously diverse societies, undergoing change among other as a result of post-migration diversification. In order to capture diverse experiences and positionalities, and as a means by which to counter pre-conceived and essentializing categories, a wide range of recruitment arenas and strategies were employed.

Research participants included more or less equal shares of men and women, in their late $20 \mathrm{~s}$ to late $50 \mathrm{~s}$, the majority of which were migrants, or had parents who were migrants, whereas they themselves came to Norway as children, with mixed socioeconomic and educational profiles. The interviews were semi-structured, and involved open-ended questions, starting with a mapping exercise in order to visualize spheres, geographies and temporalities of experiences. The interviews were conducted in Norwegian, with the exception of two which were conducted by the author in Polish.

The analysis has drawn on an inductive approach, where participants' own sensemaking of their experiences within and across scales and spheres, temporalities and geographies, has been a driving force. Specific details about participants' backgrounds have in some instances been altered for reasons of confidentiality, given the politicized and sensitive nature of some of the contexts discussed.

\section{Multiscalarity in experienced interactions of migrant transnationalism and integration The perspectival scale}

Claudine came as a refugee to Norway from Rwanda, 10 years ago and is a parent, who like many other parents, is involved in her children's lives, seeks to ensure an adequate income for her family to pursue a good life, and wants to do her bit to contribute to the world around her. But as we discuss her professional experiences, Claudine's story is one where different spheres, geographies and temporalities result in friction. This is reflected in the sense of urgency in her voice, the frustration in her notetaking on the mapping chart on the table.

${ }^{2}$ www.prio.org/act 
Claudine came to Norway alone with her elder child, and later had another child in Norway. She had trained as a nurse in Rwanda, and her dedication to working in the health sector was something she brought with her. Following several years in the asylum system, alone in Norway with her young child, and trying to support her husband who was still on the way to Europe, she learnt Norwegian and was able to get work as an assistant nurse. Her ambitions and hopes for the future, to work as a nurse, were complicated by the need for documents to prove her nursing training from Rwanda, without which she would need to start from scratch; but also by the birth of her second child, her husband's efforts to also requalify and get work equivalent to his education, confounded by the structure of the assistant nurse labour market in Oslo, characterized by part-time and temporary contracts.

Having tried hard for a long time, Claudine had nearly given up becoming a fully trained nurse in Norway. At the time of the interview she had a permanent small part-time position, and some temporary contracts. Her approach was coloured by her life story and experience in Rwanda and in Norway, but especially by a sense that there was no hope that she could achieve becoming a nurse. Claudine reflected on the fact that no one had asked her about her career plans when settling in Norway, about her ambitions and hopes, and which opportunities their might have been for her to achieve them.

For Claudine wants to contribute, to help people. The dignity of the terminally ill, of elderly dementia patients, with whom she works, are close to her heart. Even if her Norwegian skills are informally questioned by her employer, she knows she is more than able to provide the needed presence and care to her patients. But Claudine wanted to do more, yet in the sphere of working life is a story of unfulfilled hope and increasing disillusionment. There is a clear sense that the taxonomical and nested scales that the nation-state system provides, at once giving Claudine and her family sanctuary as refugees, and simultaneously from her perspective, blocking her way to become a nurse, create friction.

As reflected at the outset, Claudine is engaged in parental activities, yet her personal drive to help fellow human beings, is structurally constrained. This experience is not isolated from the rest of Claudine's life. The realities of economic hardship in a precarious labour market are a challenge to finding your feet in a new country, and thus affect how she can engage across different spheres. The death of her husband's mother brought on a sudden trip to Rwanda, which the family re-organized for financially, reprioritizing, borrowing money, and taking on extra shifts wherever possible at work. The importance of her husband being present with his siblings, having the opportunity to grieve, was something which could not be valued in monetary terms, despite the very real economic costs.

Thus, the emergent scales of Claudine and her husband - deeply embedded in their migrant experience within a transnational social lifeworld, are in friction with those of a taxonomical and nested scalar logic. This renders a sense that their perspectival scales are somehow less valid than those of the taxonomical order of the nation-state in Norway, leading to an experienced friction. For Claudine and her family, a multiscalar approach to the interaction of transnationalism and integration, reveals not only friction, but also that asymmetries of perspectival scales, where transnational realities are not acknowledged or accounted for in relation to integration, which increases the sense of friction. 


\section{Aligning emergent and perspectival scales}

Yacob has lived in Norway his entire adult life, arriving in Norway as a student, escaping war in Eritrea. His spaces of everyday life include being a parent engaged in his children's sports activities, but also a professional career which has balanced his desire to help humans in need, with challenges in an increasingly precarious Norwegian labour market, and concerns regarding his children's educational pathways. As a long-term resident in Oslo, Yacob is a reference point for many newly arrived Eritreans, seeking guidance in Norwegian society. Yacob remembers what it was like, back when he arrived, and acknowledges that not only has he changed, but so has Norwegian society. His engagements span parental, co-migrant, diasporan, religious and political engagements. Discussing intersections of everyday life and multiple geographies, Yacob says:

You know, it's impossible to focus on what is needed here and now, on remembering that extra thermos flask your kid was meant to bring to school that morning, when the night before you receive a phone call that yet another young Eritrean woman has been kidnapped in the Sinai desert, trying to seek sanctuary somewhere. It's not that you don't care, not at all, it's just that, well, your mind is elsewhere

Packing his daughter's thermos flask, is a mundane activity, but one which is important to his daughter when spending the day in a Norwegian forest, and important to Yacob as a parent, confirming both his understanding of the practical significance for her, and at a more abstract level of making sure he fits in the society in which he has effectively made the decision to raise his children.

Meanwhile the phone call about the Eritrean woman kidnapped in the Sinai desert, is a concrete plea for help, and a call for action. It is a call for action that mobilizes Yacob and his extended Eritrean network in Oslo, Norway and the wider diaspora. The mobilization is triggered by a need for immediate action in order to save another human beings' life; who is in imminent danger at the hand of brutal kidnappers. Yacob contrasts this with the mundane, every day, task of filling a thermos flask with a hot drink for his daughter.

Yacob's reflection on physical presence in Oslo, coupled with a mental presence elsewhere, is a key trait of the migrant experience, and acutely so for many people leaving conflict-ridden contexts. As Anna Lindley writes: 'the early morning phone call' (2010) from back 'there', whether with news, a desperate plea for assistance, or a simple request for some help, cannot fail to affect everyday life 'here'. Yet, for Yacob and others', the separation of 'here' and 'there' makes little sense as both are integral dimensions of their lives, and there is an inherent simultaneity as events unfold in multiple locations. The simultaneity, however, also creates friction - as the very mundane and benign, runs parallel to extreme danger and inhumanity - at an emotional level, but also in efforts to align very differing perspectival scales, where emergent scales of experiences point in contrasting directions.

\section{Transcending the logic of nested and taxonomical scales}

Maria's spaces of everyday life centre on her role as a single parent, but also as a black woman living in Oslo. As for many migrants, professional aspirations drawing on 
educational trajectories interrupted by international mobility are challenged by integration processes. Her neighbourhood is one where she is often reminded of her difference, foremost as someone poor in comparison to the well-off neighbourhood she lives in.

Maria's engagements are multiscalar not only at the local levels of neighbourhood or city. Societal development for Maria hinges on a memory of the past, which is linked with an understanding of the present and a vision for the future, which acknowledges the multiscalarity of human experience. She works, part-time, in a museum with cultural heritage. Simultaneously, her interest in cultural heritage, combined with her roots in Congo, and seeing the future of her children in Norway, leads her to seek new opportunities:

it's a project that inspired me (I...) it's something I came up with after hearing - I proposed to study objects from Congo, because they [at a museum] were having difficulties with them. They were spending lots of money on conservation, but didn't have a lot of information, nor documentation about the objects. And that's when I asked if could be involved, have it like a project. It was approved, but without funds. So I do it, because I find it interesting (...) They [the museum] are interested in the project. I have been to see the archive and there are more than 4000 registered objects in their database from Congo in Norway. I have started with the project. I feel this is something useful and interesting thinking about my own history

Maria was supported by staff at the museum, supervising the conservation work and supporting her ambitions to develop an exhibition. The exhibition became reality a year after the interview was conducted, the process involving seminars with the Congolese diaspora in Norway, and positive reception. Meanwhile, Maria is supporting her little family, through her part-time job at another museum, whilst finalizing her education. This reveals a degree of friction, where Maria's experienced and emergent scales are multiple - anchored in different spheres, geographies and temporalities. These include both recognition and a precarious work situation, leading to perspectival scales which transcend the logic of taxonomical, nested scales. Walking with Maria after the interview, she reflected:

the way I think about it, life unfolds itself and I am part of everything: my family, I am part of Congo and of Norway, and everything that happens around me. That makes me who I am. I can't devote all my life here, and say that I will only attend church and be involved in church, no, that's not possible, because I am a human and affected by my little family, with my child, and my child is part of sports and school and that's how it becomes important for me to take part in that as well. And in terms of Congo, I have to be part of the diaspora, for my children as well, and then my work, this is where I make the money I need.

As is revealed in what Maria says - the emergent scales of her everyday life are not nested and taxonomical, yet they are grounded. 


\section{Interlocking scales}

In Khiem's descriptions of the spaces of his everyday life, his roles as a parent and husband, a Catholic and as someone enjoying football, as a Norwegian citizen and as someone identifying with the Vietnamese diaspora, as employed in the health sector and as a human rights activist, all came across. The location of Khiem's everyday life was predominantly in Oslo, Norway, although he traveled all over the world, in connection with his transnational political engagement.

As we started the interview, Khiem apologized for being late, he came straight from a parent meeting at his son's nursery, where, as is customary in Norway, towards the end of the meeting a representative for the parent's council is appointed:

what happened (laughing) ... Well, I am sure everybody had valid reasons not to volunteer ... it was all quiet and I didn't think anyone would do it. Then I thought that I have more than enough to do, but I am sure I could do a little more. And then I also thought that this is a nice way to get involved in my son's day-to-day life

Khiem's motivations for what he does, are spatially anchored in multiple geographies, and there is a temporal and familial interplay, where a nested approach to scales in a taxonomical sense appears insufficient:

I am going to live in Norway for the rest of my life and this despite of my involvement for Vietnam, and I wish to contribute in Vietnam and if I have the opportunity to, I would like to travel to Vietnam and help out there. But I think the rest of the family wants to live here in Norway. Let's say, if I went to Vietnam for a short time, but I am going to be here [in Norway] forever... With that I think it is important that I establish myself in working life and within society, and be socially involved and with work, and try to be involved and help out if possible

For Khiem his political engagements are clearly transnational, and oriented towards Vietnam. Yet, he does not travel to Vietnam, but to other diaspora hubs, and to him these geographic locations, together with locations in Vietnam and in Norway constitute a meaningful spatial unit, where his life plays out. Not long ago, Khiem said:

we had this thing, a memorial for all the refugees who came with boats was to be set up, this was in collaboration with the municipality of Oslo. Then the embassy [Vietnamese] wrote a formal complaint to the municipality of Oslo and told them to stop this monument, if not there would be repercussions

The memorial indeed caused diplomatic stir, and was delayed for several years, but was finally unveiled in $2015 .^{3}$ Meanwhile, the multiscalarity of transnational politics becomes evident from this example, pointing not only to the roles of Khiem and others who were actively in favour of the memorial, but also to dividing lines among the Vietnamese diaspora, as well as the ways in which politics in Norway became integrated

${ }^{3}$ http://www.imaging.no/minnesmerket-sjoblomst/ (accessed December 2018). 
with Vietnamese politics through the embassy's involvement. Here the taxonomical, emergent and perspectival scales interlock in varying ways.

\section{Unpacking the interactions of migrant transnationalism and integration}

Returning to theorization of interactions between migrant transnationalism and integration, and what constitutes an experience of membership 'here' and 'there', the above experiences offer some key insights. On the one hand, it is not straightforward to disentangle the 'here' and 'there' of where life is anchored: is it conditioned on physical presence? Or on mental presence, as indicated by Yacob's story of his daughter's thermos flask and the transnational mobilization for an Eritrean woman kidnapped in the Sinai desert? The simultaneity - and inherent friction in this story - are two key elements in taking the theorization of interactions of migrant transnationalism and integration further. It is necessary to not leave the focus on the locatable and measurable activities here and there, but also to give equal weight to those things which a focus on emergent scales allows us to grasp.

On the other hand, it is possible to point to instances of interactions from the above experiences which are locatable in a 'here' and a 'there', and which might be typologised as additive, synergistic and antagonistic examples of interactions of migrant transnationalism and integration (Erdal and Oeppen 2013). Starting with potential antagonistic interactions, Yacob's example of a physical presence and mental absence is relevant. Because of something happening elsewhere, Yacob might (theoretically) be assumed to be distracted from practices ensuring his membership of society, in everyday life in Oslo. By contrast, had he not focused on the elsewhere, his membership in the transnational community of Eritreans in the diaspora, closely connected to people in Eritrea itself, could be seen to be at risk. At the face of it, the combination of physical presence and mental absence 'here', with a physical absence and mental presence 'there', might be assumed to work in an antagonistic way, although this would assume a zero-sum approach to belonging, which there are good reasons to question.

Claudine's story of her husband's sudden travel to be present at his mother's funeral is an example that might be counted as an antagonistic interaction of activities 'here' and 'there'. Financial priorities 'here' were re-organized, in order to attend to familial obligations 'there' (Carling et al. 2012). However, it is perhaps more of a leap to argue that this has clear adverse implications 'here', in the long run, although in the short term this was the case. 'There' implications would have been more adverse perhaps had Claudine's husband not travelled, in the sense of upholding a sense of remaining a member who belongs 'there'.

Both of these examples, as many other above may, however, be interpreted in alternative ways. For, in the lives of Claudine, Yacob, Maria and Khiem, instances of interactions between transnationalism and integration, may simultaneously entail antagonistic aspects, as discussed above, but might also be seen in additive terms, running parallel and to some extent following logics isolated from one another, such as in the case of Yacob and his daughter and the woman in the Sinai desert. Claudine's husbands travel to his mother's funeral might also be seen in additive terms, whether for him or them as a family, there were simultaneous activities in Norway and in Rwanda, which in

${ }^{3}$ http://www.imaging.no/minnesmerket-sjoblomst/ (accessed December 2018). 
some ways simply added to the level of activity, not necessarily directly affecting each other so much. Possibly, there could be a synergistic interpretation, whereby because Claudine's husband could travel to his mother's funeral, he felt more fulfilled and later invested more intensively in gaining his qualifications, having gotten the possibility to say a proper farewell, and experience some shared closure with his siblings, confirming membership and belonging 'there'.

Yet, these are only fragments of two of the stories, and such a reading of interactions between migrant transnationalism and integration, tries to categorize migrant experiences in ways which run counter to the multiplicity of their lived experience. As the stories reveal, there are instances where their sense of membership of societies, may entail an additive interaction, a synergistic one, or an antagonistic one. Meanwhile, the fact that multiple locations, scales and spheres overlap and clash, necessitates an analysis which allows space for friction beyond a geographic 'here' and a 'there'. In order to extend the theorization of interactions of migrant transnationalism and integration beyond a focus on the 'here' and the 'there', two dimensions merit further analytical scrutiny: simultaneity and friction.

First, we must pay closer attention to the salience of simultaneity in lifeworld's that are spatially anchored in multiple geographies. Geographies in the sense of specific locations of presence and of absence; usually tied to relations with other people. The relevance of different locations in migrants' lives, suggests that their interplay and the very simultaneity thereof, is a key element of what is being experienced, and thus contributing to emergent scales of interpretations of one's own life but also of the world around.

However, acknowledging the fact of simultaneity is not enough: simultaneous membership (partly or fully) in two societies, necessarily comes with friction. In Waldinger's (2017) terms a dissimilation from the societies of origin, paralleled with the experience of xenophobia (and xenophilia) in societies of settlement, results from a two-sided cross-border friction.

Therefore, and secondly, we must pay attention to friction. Friction, as discussed by Anna Tsing (2005), is caused and revealed through interconnectedness and a crucial aspect of migrant experience. Different spheres, geographies and temporalities, which come together in migrant transnationalism and integration, inevitably result in friction. Yet, whilst such friction may be seen as inherently problematic and inevitably untenable (Waldinger 2017), or in relation to globalization referred to in terms of a 'clash of civilizations' (Tsing 2005), an alternative reading is possible.

For friction is not only a result, rather friction may also produce movement, action and effect, reflecting conflicting social interactions in an interconnected world (Tsing 2005). Theorization of the interactions of migrant transnationalism and integration cannot ignore friction - yet interpreting this necessarily as a sign of an antagonistic relationship, or of an additive, rather than a synergistic one, is reductionist, and ignores the possibility of productive friction.

Analyzing interactions of migrant transnationalism and integration through a multiscalar approach, which foregrounds the roles of nested and taxonomical scales, but equally of emergent and perspectival scales, across time, space and position, prompts the realization that friction may be experienced both as productive and as destructive. The simultaneity of perspectives and experiences which are grounded 'here' and 'there' - avails migrants who are engaged both 'here' and 'there' with opportunities, but also 
challenges - financially as well as emotionally. Analyzing these opportunities and challenges from the perspective of nested, taxonomical scales - where membership simultaneously in two geographically distinct and distant societies is impossible, because you are either 'here' or 'there' does not grasp the totality of migrant experience, as evidenced in the above extracts. Instead, including - also - the possibility of multiple emergent and perspectival scales, allows for a fuller rendering of migrant experience, where friction may be experienced as both productive and destructive at different points in time.

\section{Conclusion}

Theorizing the interactions of migrant transnationalism and integration beyond a 'here' and a 'there', through the adoption of a multiscalar approach, opens up to the multiplicity of scales. Not scales simply as levels, but also types of scales as taxonomical, emergent or perspectival, and their relational production. Whilst in the analyzed four stories the interplay of the 'here' and 'there' of migrant transnationalism and integration may be interpreted as additive, synergistic and antagonistic, these individuals' experiences across spheres, locations and time, are revealing of simultaneity and friction, beyond a geographic 'here' and 'there'.

Analyzing migrants' multiscalar experiences furthers the theorization of interactions of migrant transnationalism and integration by foregrounding simultaneity as integral to experiences of interconnected geographies, spheres and temporalities of transnational social fields. Such simultaneity may be both challenging and productive, for individuals' as members of societies 'here' and 'there'. The interplay of migrant transnationalism and integration - over time and across space, is however, in need of further analytical attention, from scholars studying people's whose lives are shaped by cross-border migration.

This is perhaps a surprising claim, given the focus on migrant transnationalism - and on transnational social fields - within migration studies (Collyer and King 2015; Glick Schiller et al. 1992; Levitt and Glick Schiller 2004). However, much of this literature suffers from insufficient theoretical attention to the multiplicity of scales which are at play. In particular, the more common approach to taxonomical and nested scales, needs further complementing by a focus also on emergent scales and perspectival scales (Xiang 2013). Adopting a multiscalar approach to migrants' experiences, where emergent and perspectival scales are in focus, contributes to moving debates beyond a focus on a 'here' and 'there', as spatially disjointed and separate locations, that must fit within a taxonomical, nested scalar order.

This is not to say that taxonomical, nested scales may not be as relevant as emergent and perspectival scales, for this may well be the case. Rather, it is an argument for an analytical openness, as to what kind of interplay there is between different types of scalar constellations - as dynamic constructions - which become apparent by adopting a multiscalar approach. 
Funding - grant no.

We are grateful to the Norges Forskningsråd (Research Council of Norway) [award number 236882] for supporting this research.

\section{Author's contributions}

This is a single-authored paper by this author. The author(s) read and approved the final manuscript.

\section{Funding}

As is described in the article's methods section, the article draws on data from a research project (www.prio.org/act). The project was funded by the Research Council of Norway. There was no involvement of the Research council in any process of the research, beyond providing funding for the research time and research infrastructure to carry this work out. The Grant number: 236882 would be added in the event of publication: [Active citizenship in culturally and religiously diverse societies].

\section{Availability of data and materials}

The data which this paper draws on was collected as part of a research project funded by the Research Council of Norway (as described in the methods section). The data collection received ethical clearance on a basis where research participants were not asked, and hence did not approve of, open sharing of the data even in anonymized form. Therefore, the data set cannot be shared openly. A meta-data report for the data set could be shared on request with anyone interested. However, based on the consent received from research participants, sharing transcripts, even with names removed, would not be within the ethical bounds of what is possible. The author notes the dilemmas of data sharing in relation to qualitative data sets, in relation to on the one hand maintaining confidentiality, and on the other hand ensuring that analysis and interpretation are fully possible, given necessary removal of contextual information - and details about individual participants which would complicate anonymization.

\section{Competing interests}

The author declares that they have no competing interests.

Received: 24 June 2019 Accepted: 15 June 2020

Published online: 11 September 2020

\section{References}

Al-Ali, N., Black, R., \& Koser, K. (2001). The limits to 'transnationalism': Bosnian and Eritrean refugees in Europe as emerging transnational communities. Ethnic and Racial Studies, 24(4), 578-600.

Antonsich, M. (2010). Searching for belonging-an analytical framework. Geography Compass, 4(6), 644-659.

Bilgili, Ö. (2014). Simultaneity in transnational migration research: Links between migrants' host and home country orientation [PhD Dissertation]. Maastricht University.

Bloemraad, I. (2015). Theorizing and analyzing citizenship in multicultural societies. The Sociological Quarterly, 56(4), 591-606.

Brubaker, R. (2010). Migration, membership, and the modern nation-state: Internal and external dimensions of the politics of belonging. Journal of Interdisciplinary History, 41(1), 61-78.

Brubaker, R., \& Cooper, F. (2000). Beyond "identity". Theory and society, 29(1), 1-47.

Çağlar, A., \& Glick Schiller, N. (2015). A multiscalar perspective on cities and migration. Sociologica, 2, 1-9.

Carling, J. (2007). Transnationalism in the Context of Restrictive Immigration Policy [Doctoral dissertation]. University of Oslo, Department of Sociology and Human Geography.

Carling, J., Erdal, M. B., \& Horst, C. (2012). How does conflict in migrants' country of origin affect remittance-sending? Financial priorities and transnational obligations among Somalis and Pakistanis in Norway. International Migration Review, 46(2), 283-309.

Carling, J., \& Pettersen, S. V. (2014). Return migration intentions in the integration-transnationalism matrix. International Migration, 52(6), 13-30.

Chaudhary, A. R., \& Moss, D. M. (2019). Suppressing transnationalism: Bringing constraints into the study of transnational political action. Comparative Migration Studies, 7. https://doi.org/10.1186/s40878-019-0112-z.

Collyer, M., \& King, R. (2015). Producing transnational space: International migration and the extra-territorial reach of state power. Progress in Human Geography, 39(2), 185-204.

Cristina, E., Arana, R., \& McCann, J. (2014). Expatriate voting and migrants' place of residence: Explaining transnational participation in Colombian elections. Migration Studies, 3(1), 1-31 https://doi.org/10.1093/migration/mnt030.

Dekker, B., \& Siegel, M. (2013). Transnationalism and integration: Complements or Substitutes? (Working paper no. 071). United Nations University-Maastricht Economic and Social Research Institute on Innovation and Technology (MERIT).

Dominges, S. (2015). I'm neither here nor there: Mexicans' quotidian struggles with migration and poverty. Contemporary Sociology, 44(2), 284-285.

Erdal, M. B. (2012). 'A place to stay in Pakistan': Why migrants build houses in their country of origin. Population, Space and Place, 18(5), 629-641.

Erdal, M. B., \& Oeppen, C. (2013). Migrant balancing acts: Understanding the interactions between integration and transnationalism. Journal of Ethnic and Migration Studies, 39(6), 867-884.

Erdal, M. B., \& Sagmo, T. H. (2017). Descent, birthplace and residence: Aligning principles of citizenship with realities of migrant transnationalism. Norwegian Journal of Geography, 71(4), 208-219.

Eriksen, T. H. (2011). What is a society? Ethnicities, 11(1), 18-22.

Glick Schiller, N., Basch, L., \& Szanton-Blanc, C. (1992). Towards a transnational perspective on migration: Race, class, ethnicity, and nationalism reconsidered. New York: New York Academy of Sciences.

Gropas, R., Triandafyllidou, A., \& Bartolini, L. (2014). Conceptualising the integration-transnationalism nexus (ITHACA report). Florence: European University Institute. 
Guarnizo, L. E., Portes, A., \& Haller, W. (2003). Assimilation and transnationalism: Determinants of transnational political action among contemporary migrants. American Journal of Sociology, 108(6), 1211-1248.

Hamaz, S., \& Vasta, E. (2009). To Belong Or Not to Belong: Is that the Question?' Negotiating Belonging in Multi-ethnic London (working paper no. 73). Centre on Migration, Policy and Society, University of Oxford.

Horst, C., Erdal, M. B., \& Jdid, N. (2020). The "good citizen": Asserting and contesting norms of participation and belonging in Oslo. Ethnic and Racial Studies, 43(16), 76-95.

Itzigsohn, J., \& Giorguli-Saucedo, S. (2002). Immigrant incorporation and sociocultural transnationalism. International Migration Review, 36(3), 766-798.

Kivisto, P. (2003). Social spaces, transnational immigrant communities, and the politics of incorporation. Ethnicities, 3(1), 5-28.

Kuuire, V. Z., Arku, G., Luginaah, I., Buzzelli, M., \& Abada, T. (2016). Transnationalism-integration nexus: Examining the relationship between transnational housing investment and homeownership status in Canada. Geoforum, 75, 168-179.

Lacroix, T. (2016). Hometown transnationalism. Long Distance Villageness among Indian Punjabis and North African Berbers. Basingstoke and New York: Palgrave Macmillan.

Landolt, P., Autler, L., \& Baires, S. (1999). From Hermano lejano to Hermano mayor: The dialectics of Salvadorian transnationalism. Ethnic and Racial Studies, 22(2), 290-315.

Levitt, P. (2001). The transnational villagers. Los Angeles: University of California Press.

Levitt, P., \& Glick Schiller, N. (2004). Conceptualizing simultaneity: A transnational social field perspective on society. International Migration Review, 38(3), 1002-1039.

Ley, D. (2013). Does transnationalism trump immigrant integration? Evidence from Canada's links with East Asia. Journal of Ethnic and Migration Studies, 39(6), 921-938.

Malkki, L. H. (1995). Refugees and exile: From "refugee studies" to the national order of things. Annual Review of Anthropology, 24(1), 495-523.

Mazzucato, V. (2008). The double engagement: Transnationalism and integration. Ghanaian migrants' lives between Ghana and the Netherlands. Journal of Ethnic and Migration Studies, 34(2), 199-216.

Mazzucato, V. (2009). Bridging boundaries with a transnational research approach: A simultaneous matched sample methodology. In M. A. Falzon (Ed.), Multi-sited ethnography: Theory, praxis and locality in contemporary research (pp. 215-232). London: Routledge.

Moore, A. (2008). Rethinking scale as a geographical category: From analysis to practice. Progress in Human Geography, 32(2), 203-225.

Mügge, L. (2016). Transnationalism as a research paradigm and its relevance for integration. B. Garcés-Mascareñas, \& R. Penninx (Eds.), Integration Processes and Policies in Europe. IMISCOE Research Series (pp. 109-125). Cham: Springer.

Nagel, C., \& Staeheli, L. (2008). Integration and the negotiation of 'here' and 'there': The case of British Arab activists. Social and Cultural Geography, 9(4), 415-430.

Ostergaard-Nielsen, E. (2011). Codevelopment and citizenship: The nexus between policies on local migrant incorporation and migrant transnational practices in Spain. Ethnic and Racial Studies, 34(1), 20-39.

Portes, A., Guarnizo, L. E., \& Haller, W. J. (2002). Transnational entrepreneurs: An alternative form of immigrant economic adaptation. American Sociological Review 67(2), 278-298.

Rytter, M. (2019). Writing against integration: Danish imaginaries of culture, race and belonging. Ethnos, 84(4), 678-697.

Schans, D. (2009). Transnational family ties of immigrants in the Netherlands. Ethnic and Racial Studies, 32(7), 116482.

Schunck, R. (2011). Immigrant integration, transnational activities, and the life course. In M. Wingens, M. Windzio, H. de Valk, \& C. Aybek (Eds.), A Life-Course Perspective on Migration and Integration (pp. 269-282). Dordrecht: Springer

Smith, M. P. (2005). Transnational urbanism revisited. Journal of Ethnic and Migration Studies, 31(2), 235-244

Snel, E., Engbersen, G., \& Leerkes, A. (2006). Transnational involvement and social integration. Global Networks, 6(3), 285308.

Tsing, A. (2005). Friction: An ethnography of global connections. Princeton: Princeton University Press.

Tsuda, T. (2012). Whatever happened to simultaneity? Transnational migration theory and dual engagement in sending and receiving countries. Journal of Ethnic and Migration Studies, 38(4), 631-649.

Vink, M., Schmeets, H., \& Mennes, H. (2019). Double standards? Attitudes towards immigrant and emigrant dual citizenship in the Netherlands. Ethnic and Racial Studies, 42(16), 83-101.

Waldinger, R. (2008). Between "Here" and "there": Immigrant cross-border activities and loyalties. International Migration Review, 42(1), 3-29.

Waldinger, R. (2017). A cross-border perspective on migration: Beyond the assimilation/transnationalism debate. Journal of Ethnic and Migration Studies, 43(1), 3-17.

Waldinger, R., \& Fitzgerald, D. (2004). Transnationalism in question. American Journal of Sociology, 109(5), 1177-1195.

Wimmer, A., \& Glick Schiller, N. (2003). Methodological nationalism, the social sciences and the study of migration: An essay in historical epistemology. International Migration Review, 37(3), 576610.

Xiang, B. (2013). Multi-scalar ethnography: An approach for critical engagement with migration and social change. Ethnography, 14(3), 282-299.

Yuval-Davis, N. (2010). Theorizing identity: Beyond the 'us' and 'them' dichotomy. Patterns of Prejudice, 44(3), 261-280.

\section{Publisher's Note}

Springer Nature remains neutral with regard to jurisdictional claims in published maps and institutional affiliations. 